\title{
Pitch production during the Roman period: an intensive mountain industry for a globalised economy?
}

Hector A. Orengo ${ }^{1,2}$, Josep M. Palet ${ }^{2}$, Ana Ejarque ${ }^{2,3}$, Yannick Miras $^{4,5} \&$ Santiago Riera ${ }^{6}$

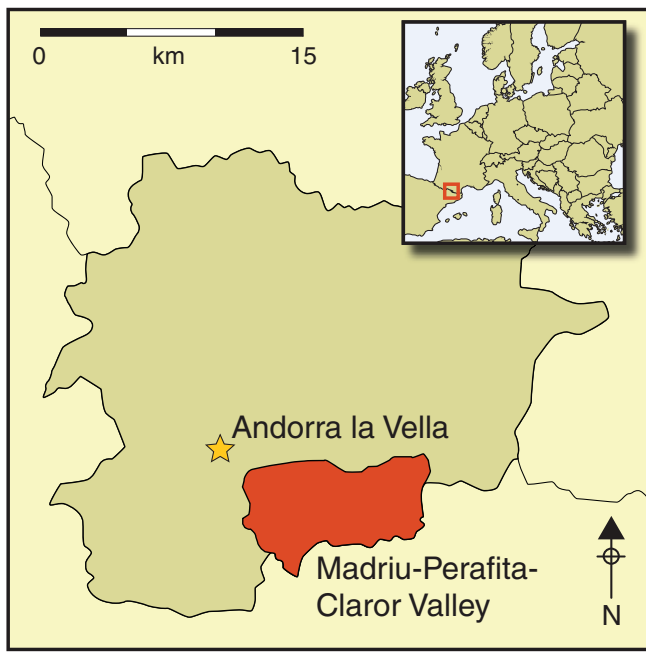

The authors' research project in the Pyrenees mountains has located and excavated Roman kilns for producing pitch from pine resin. Their investigations reveal a whole sustainable industry, integrated into the local environmental cycle, supplying pitch to the Roman network and charcoal as a spin-off to the local iron extractors. The paper makes a strong case for applying combined archaeological and palaeoenvironmental investigations in upland areas, showing mountain industries to have been not so much marginal and pastoral as key players in the economy of the Roman period and beyond it into the seventh century $A D$.

Keywords: Pyrenees, mountain landscape, Roman period, pitch, pine, resin, iron

\section{Introduction}

Tree resin and its derivatives, such as pitch or tar, played an important role in the past and constituted some of the most wanted products in antiquity. Pitch was supplied widely in the Mediterranean and North Atlantic regions, implying an industry not only directed towards local or regional commerce but with a much wider distribution and reach. 20

\footnotetext{
Department of Archaeology, University of Nottingham, University Park, Nottingham NG7 2RD, UK

2 Landscape Archaeology Research Group (GIAP), Catalan Institute of Classical Archaeology (ICAC), Plaza Rovellat s/n, 43003, Tarragona, Spain

3 Environmental Programs, School of Earth Sciences and Environmental Sustainability, Northern Arizona University, Flagstaff, AZ 86011, USA

4 CNRS, GEOLAB, UMR 6042, Laboratoire de Géographique physique et environnementale, 4 rue Ledru, F-63057, Clermont-Ferrand, France

5 Clermont Université, Université Blaise Pascal, GEOLAB, Maison des Sciences de l'Homme, BP 10448, F-63000, Clermont-Ferrand, France

6 Seminar of Studies and Prehistoric Research (SERP), Department of Prehistory, Ancient History and Archaeology, University of Barcelona, Calle Montalegre 6, 08001, Barcelona, Spain
} 
Roman shipwrecks in the Mediterranean have yielded evidence of resin transport in their cargo (Parker 1992), some of which included particularly large quantities of this product, such as the Dramont F wreck (fourth century) with a cargo of around 120 amphorae full of resin (Joncheray 1977). Of particular interest is the half a ton of pitch recovered from the third century Gallo-Roman ship in Saint Peter Port (Guernsey, UK; Rule \& Monaghan 1993), probably deriving from a production centre in the Landes area of France (Connan et al. 2002).

The terms 'tar' and 'pitch' have been used interchangeably in the literature, mainly because both terms relate more to technological process than to chemically defined entities. They both refer to a heated derivative of either the bleed resin or the resin extracted from wood by heat, although pitch is also considered to derive from the heating of tar (e.g. Abraham 1920: 27). More recent reports on the distillation of resinous wood consider their production as depending upon the temperature applied (Beglinger 1958: 3). In this paper we will employ the term pitch for convenience, as the origin of this word derives from the Latin word pix, which, as Pliny acknowledges (Naturalis Historia 23.24; Bostock \& Riley 1855) was specifically applied in antiquity to distilled resin (André 1964).

During the Roman period, pitch was used in the preparation of medicinal unguents; to season wines; for construction and lighting purposes; as a glue or incense, etc. However, its most widespread use was for the waterproofing of containers, including wooden casks, amphorae and dolia, for which enormous quantities of this substance would have been needed. Nonetheless, archaeology has paid little attention so far to the production of such an important commodity, most of the published data relating to its identification in archaeological contexts (Connan et al. 2002). Here we present new evidence for pitch production during the Roman period in the Iberian Peninsula, as recorded within the framework of a major research project in the Madriu-Perafita-Claror Valley (MPCV) (Palet et al. 2011). The production cycle followed at the site is determined and placed in its environmental and economic context. In addition, we offer a general overview of the role of the pitch industry from production to distribution.

\section{The MPCV project}

The MPCV is located in the south-eastern part of Andorra, in the eastern Pyrenees (Figure 1). This high-mountain area, ranging from 1050-2905m asl, is dominated by pine (Pinus mugo ssp. uncinata) woodland with Alpine grasslands from $2300 \mathrm{~m}$ asl. A combination of landscape archaeology techniques, including total-coverage extensive survey and site excavation, as well as fine resolution multi-proxy palaeoenvironmental analyses, have been employed (Ejarque 2009; Orengo 2010). The survey has located the sites of seven pitch kilns (prefixed M or P on Figure 1). Analysis of historical sources and ethnographic data was then used to help interpret and contextualise the archaeological data. Palaeoenvironmental analyses in peat records included pollen, non-pollen palynomorphs (NPPs), macro-charcoal and pine stomata. Of relevance for this study are the sequences at Riu dels Orris (RDO) (Ejarque 2009; Ejarque et al. 2010) and Bosc dels Estanyons (BDE) (Miras et al. 2007), located at a maximum distance of $700 \mathrm{~m}$ from the different pitch kilns (Figure 1). The integration of palaeoenvironmental and archaeological data was achieved by employing high-resolution 


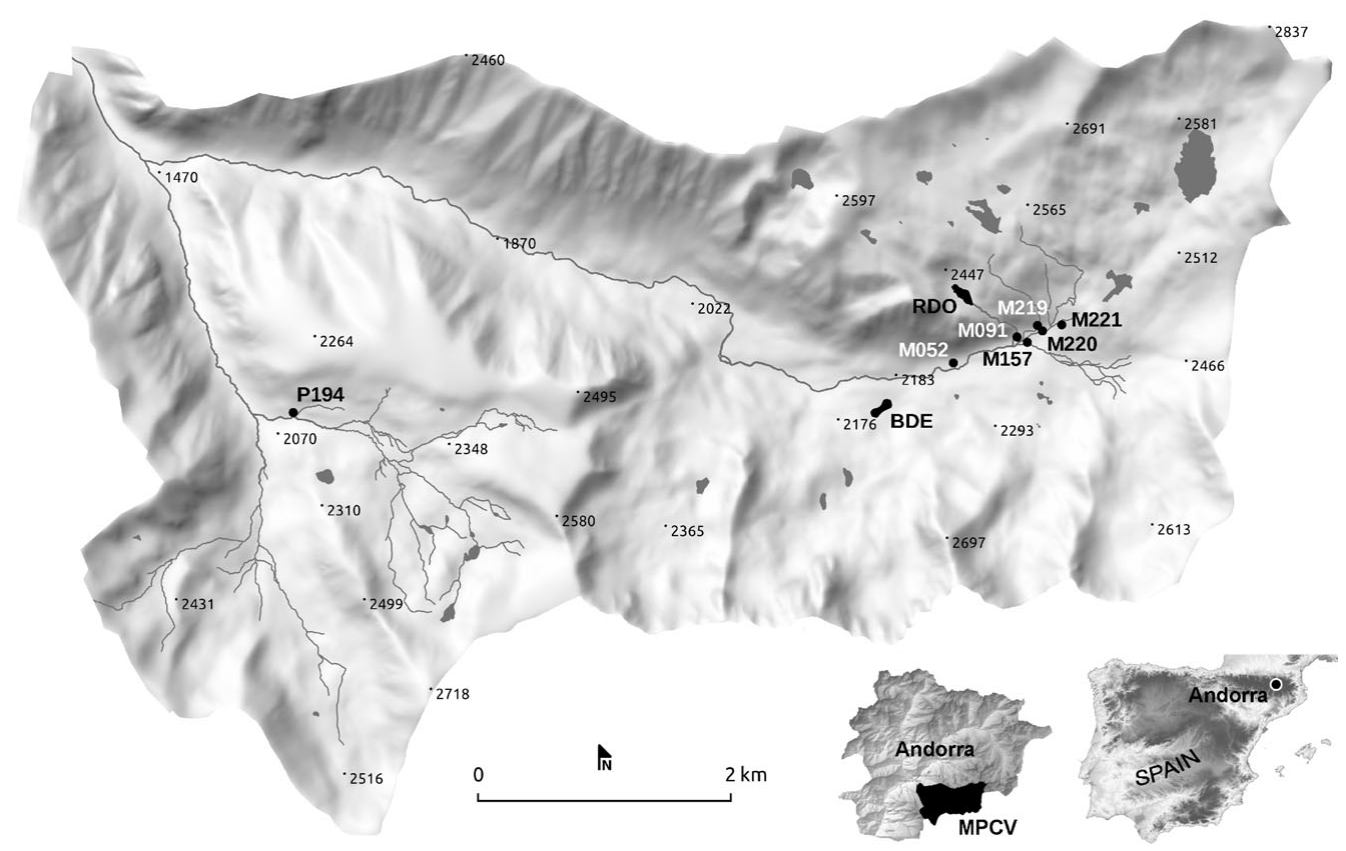

Figure 1. Location of the Madriu-Perafita-Claror Valley (MPCV) project area in Andorra, showing the location of kilns (M and $P$ ) and palaeoenvironmental sequences (RDO and BDE) mentioned in the text (C) H.A. Orengo).

chronological and spatial parameters. Peat profiles had an accurate chronological framing, with a range of four to eight radiocarbon dates. At the RDO site, a fine-resolution pollen analysis was conducted for the samples dated to antiquity, with the analysis of contiguous $10 \mathrm{~mm}$ samples, each comprising around 40 years of pollen rain (Ejarque 2009).

The kilns were radiocarbon-dated using small fragments of organic material trapped inside the mortar at the time of the construction of the kiln, or charcoal fragments relating to its last use (Table 1). Anthracological analysis documented the wood species, log diameters, degree of carbonisation and any marks left on the wood that could hint at its handling (Euba 2009a).

\section{The pitch kilns}

Seven kilns, six in the Madriu Valley and one in the Perafita Valley, were identified at heights between 2196 and $2285 \mathrm{~m}$ asl. Of these, the well-preserved M052 and M157 were excavated, while M091, M219 and M220 were poorly preserved and thus only recorded after surface cleaning. M221 and P194 only produced fragments of kiln wall and charcoal. Radiocarbon dating (Table 1) showed a non-continuous resin exploitation between the second and seventh centuries AD.

M157 (Figure 2) had a circular plan around $1.8 \mathrm{~m}$ in diameter with baked clay walls about $100 \mathrm{~mm}$ thick, preserved to a variable height of around $300 \mathrm{~mm}$ (Palet et al. 2011). The foundation consisted of a pavement of flat stones laid on scorched earth. The pavement

(C) Antiquity Publications Ltd. 
Table 1. Radiocarbon dates framing the use of the resin kilns (calibration curve from Reimer et al. 2009).

\begin{tabular}{|c|c|c|c|c|c|c|c|}
\hline Code & Exc. date & Site & Structure & SU & Description & Date ${ }^{14} \mathrm{C}$ & $\begin{array}{l}\text { Date }{ }^{14} \mathrm{C} \\
\text { cal } 2 \sigma\end{array}$ \\
\hline Poz-13626 & July 2005 & $\begin{array}{l}\text { Pla de } \\
\text { l'Ingla III }\end{array}$ & M052 & 107 & $\begin{array}{l}\text { Wood prepared for the } \\
\text { kiln's last use }\end{array}$ & $\begin{array}{l}1860 \pm \\
30 \mathrm{BP}\end{array}$ & $\begin{array}{l}155 \pm \\
76 \mathrm{AD}\end{array}$ \\
\hline Poz-32019 & July 2009 & $\begin{array}{l}\text { Riu dels } \\
\text { Orris III }\end{array}$ & M219 & 101 & $\begin{array}{l}\text { Charcoal from the kiln's } \\
\text { last use }\end{array}$ & $\begin{array}{l}1875 \pm \\
30 \mathrm{BP}\end{array}$ & $\begin{array}{l}147 \pm \\
77 \mathrm{AD}\end{array}$ \\
\hline Poz-22563 & July 2007 & $\begin{array}{l}\text { Riu dels } \\
\text { Orris III }\end{array}$ & M157 & 401 & $\begin{array}{l}\text { Carbonised wood } \\
\text { fragment in the wall }\end{array}$ & $\begin{array}{l}1740 \pm \\
30 \mathrm{BP}\end{array}$ & $\begin{array}{l}312 \pm \\
\quad 77 \mathrm{AD}\end{array}$ \\
\hline Poz-28428 & July 2008 & $\begin{array}{l}\text { Riu dels } \\
\text { Orris III }\end{array}$ & M157 & 711 & $\begin{array}{c}\text { Charcoal inside the } \\
\text { evacuation hole }\end{array}$ & $\begin{array}{l}1505 \pm \\
30 \mathrm{BP}\end{array}$ & $\begin{array}{l}537 \pm \\
100 \mathrm{AD}\end{array}$ \\
\hline Poz-32024 & July 2009 & $\begin{array}{l}\text { Riu dels } \\
\text { Orris III }\end{array}$ & M091 & 101 & $\begin{array}{l}\text { Charcoal from the kiln's } \\
\text { last use }\end{array}$ & $\begin{array}{l}1480 \pm \\
30 \mathrm{BP}\end{array}$ & $\begin{array}{l}592 \pm \\
51 \mathrm{AD}\end{array}$ \\
\hline Poz-32020 & July 2009 & $\begin{array}{l}\text { Riu dels } \\
\text { Orris III }\end{array}$ & M220 & 101 & $\begin{array}{l}\text { Carbonised wood } \\
\text { fragment in the wall }\end{array}$ & $\begin{array}{l}1430 \pm \\
30 \mathrm{BP}\end{array}$ & $\begin{array}{l}616 \pm \\
42 \mathrm{AD}\end{array}$ \\
\hline
\end{tabular}

was covered with baked clay, creating a smooth surface sloping towards an orifice $200 \mathrm{~mm}$ in diameter on the lower part of the wall. This evacuation hole and the sloping pavement indicate that the furnace was directed towards the production of a substance distilled by the action of fire. The evacuation hole preserved sediment and material from the kiln's last use in its cylindrical shape. Several carbonised pine logs (Pinus mugo ssp. uncinata) were found in this enclosed space. They correspond to branches of around $100 \mathrm{~mm}$ diameter, which included remains of resin still seen on the surface of the wood both macro- and microscopically (Euba 2009a) (Figure 3). The evacuation hole should have led through a baked-clay channel to a reservoir, but this was not located. The unexcavated M219 and M220 had channels departing from the kilns towards a common point where a receptacle for the liquid pitch would have been located.

During the excavation of kiln M052 a group of carbonised logs was found piled beside the kiln after the distillation process (Figure 4). Their diameters were similar to those from M157 and their lengths varied from 0.4-0.5m. Axe-marks were visible on their ends (Euba 2009b: 87-95). These kilns were interpreted as intended for the production of pitch from pine resin, and studied in the context of such knowledge as has survived in ancient literature and previous archaeological finds.

\section{Literary and archaeological parallels}

In his Naturalis historia (16.21; Bostock \& Riley 1855) Pliny explains that pitch is obtained from chopped logs of taeda (resinous pine-tree or pitch-pine, which has been identified as the Pinus mugo; see Bostock \& Riley [1855: book 16, notes 20 and 35]) in Europe. These are placed into a furnace that is heated from the outside by means of fires surrounding it until the wood exudes its resin, which then flows into a specially made reservoir for collection. In his Enquiry into Plants (9.3; Hort 1916) Theophrastus gives an account of the methods employed for extracting pitch in Macedonia and Syria: pine-wood logs were heaped on a 


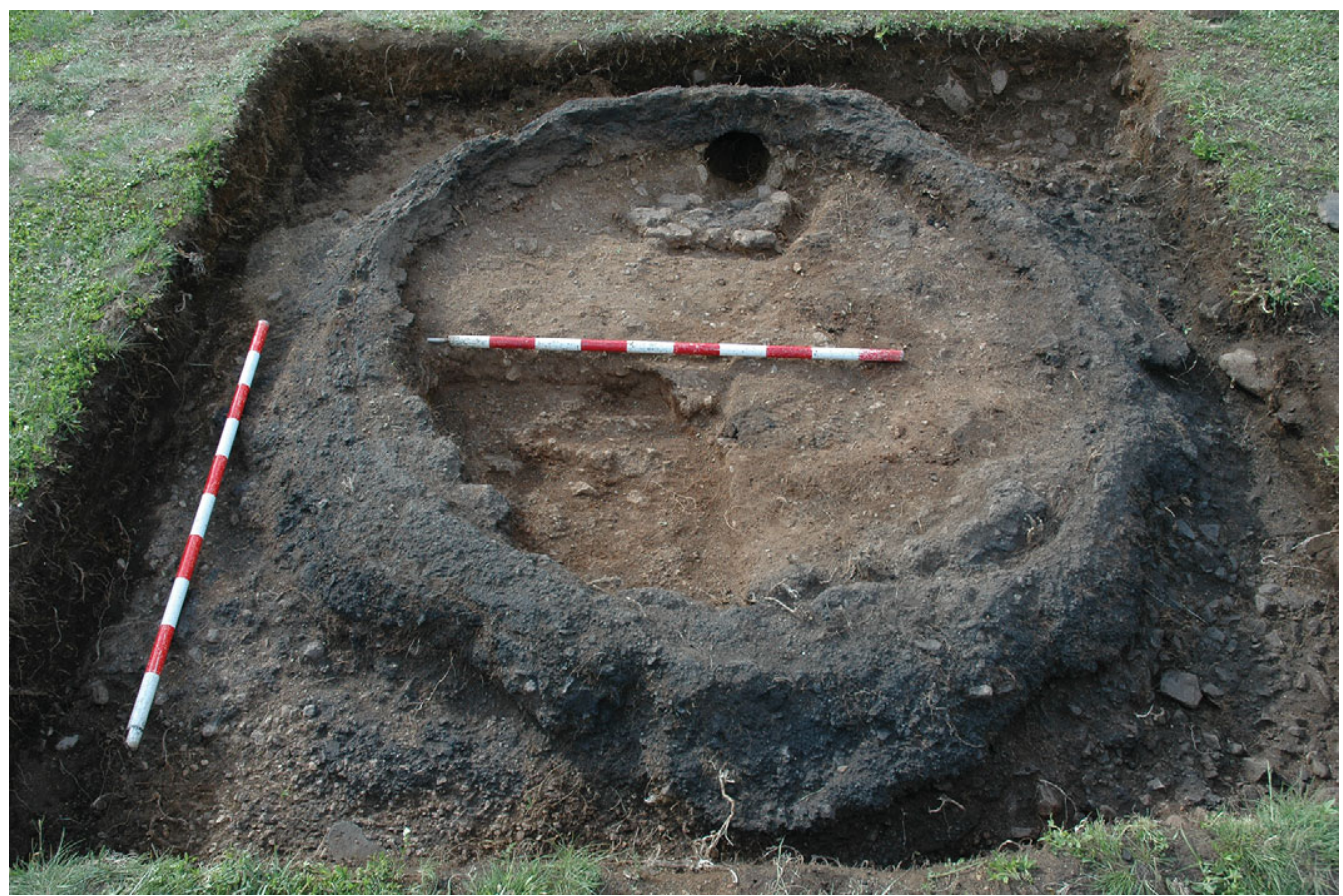

Figure 2. Kiln M157 after excavation (c) J.M. Palet).

sloping piece of cleared ground, covered with earth and fired as in charcoal-burning. The resin contained in the logs was exuded by the action of heat and, in a liquid state, flowed down the slope through a conduit leading to a hole outside the structure. Although the methods described by the two texts are slightly different, both aim at gathering tree resin by exuding it from heated wood.

Archaeological evidence for resin production in the Roman period has been scarce and mostly confined to the Causses region of the French Massif Central (e.g. Loir 1940; Viré 1943; Albenque 1947; Soutou 1959; Trintignac 2003), but there are also examples from the Haut-Forez, further north in the Massif Central (Renaud 1963); the Sanguinet lake, Landes (Balsan 1951); Oberbronn, Alsace (Ulrich 1939) and East Middle Sweden (Hjulström et al. 2006). All the sites in Celtic France employ pairs of big ceramic conical containers. The first of these is buried while the second, containing pine logs, is located in an inverted position on top of the first, and the space between their rims is sealed with clay. A fire built on the surface around the upper container makes the logs exude the resin, which accumulates in the bottom container. As in the method described by Pliny, the fire is external to the structure and has no direct contact with the pine logs (Soutou 1959: 87-88).

At Oberbronn, a bowl shaped depression in the ground, about $2 \mathrm{~m}$ in diameter, was roughly paved with bricks and limestone slabs. Ulrich (1939) suggests this platform was used for a pile of logs, which would have been covered by a thick layer of clay and then lit. The slow combustion, similar to that of a charcoal mound, would have made the wood exude the resin, which, as suggested by Ulrich, would have been (C) Antiquity Publications Ltd. 
collected outside the mound via a conduit. This type of pitch production by internal heat is similar to that described by Theophrastus (Enquiry into Plants 9.3; Hort 1916).

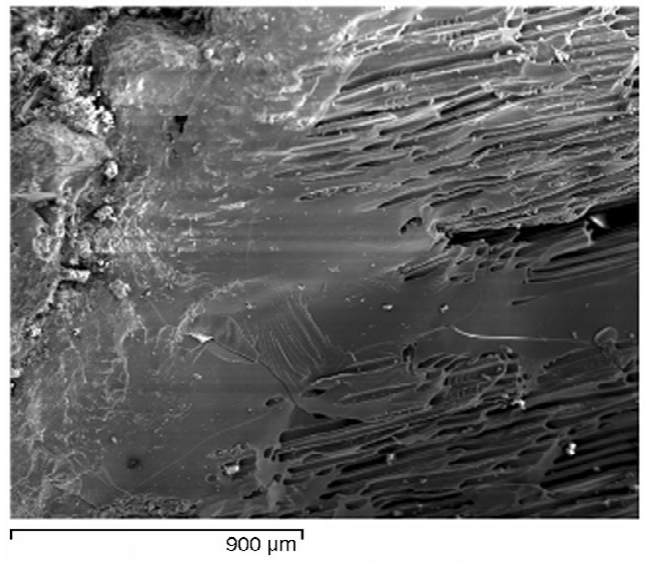

Figure 3. Micro-photograph of pitch adhered to the surface of the boughs inside the M157 evacuation hole (c) I. Euba).
In the province of Uppland in East Middle Sweden six pitch production pits were investigated and dated to AD 240 540 (Hjulström et al. 2006). Pitch was obtained from Pinus sylvestris following a different process: a funnel-shaped hole was excavated in the upper level of a terrace. The upper part of the structure was filled with logs and then covered with soil and kindled. The distilled pitch descended until it reached the bottom of the structure where a pipe would carry it outside the lower part of the terrace. As in the case of the Oberbronn kiln, the distillation of resin is achieved by internal heat allowing the production of charcoal at the same time.

Later Medieval pitch kilns from the Montseny Massif offer a parallel for the appearance of the Andorran kilns (Figure 5). They are similar in plan and size, although the walls are noticeably thicker, probably due to the height of the structure, being about $2 \mathrm{~m}$ high with a conical shape. The medieval ovens have three openings, one on top to control the air entrance and burning rhythm, one at the front to load the logs and unload the resulting charcoal and one at ground level corresponding to the resin evacuation hole.

These analogies identify the MPCV features as kilns for resin extraction similar to those described by Theophrastus (Enquiry into Plants 9.3; Hort 1916). In this case, the wood is carbonised by contact with fire during the distillation process, and the floor of the kiln is sloped for the pitch to flow towards an evacuation hole that leads to a pool. This provides for the production of both resin and charcoal.

\section{The production cycle}

Palaeoecological evidence provides further insights into the working of this type of Roman forest exploitation. The Bosc dels Estanyons pollen sequence, $700 \mathrm{~m}$ south-west of M052 kiln, records a local clearance of the subalpine pine forest and expansion of grasslands in the second century $\mathrm{AD}$ (when the earliest kilns were in use). The trees were not cleared by fire (Miras et al. 2007). The Riu dels Orris sequence located $500 \mathrm{~m}$ away from the concentration of kilns (M091, M157, M219 and M220) indicates both strong pine-clearing episodes linked to an increase in herbaceous pollen taxa in the area and a low fire frequency (Ejarque 2009). Both sequences suggest a deforestation process by tree felling (Ejarque et al. 2010). This is in accordance with the axe marks recorded on the logs from M052 kiln, highlighting an existing relationship between pine clearance and pitch production.

The fine resolution pollen analysis performed at the RDO peat sequence provides further support to this suggestion. When initial and final radiocarbon dates for the kilns' activity 


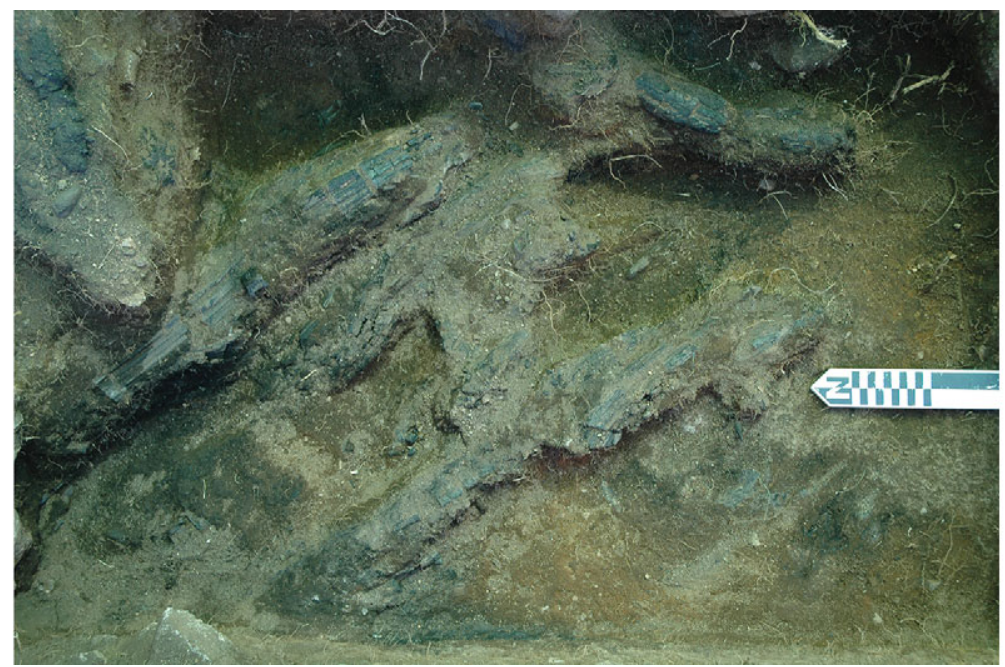

Figure 4. Carbonised logs piled after resin distillation in kiln M052 (c) J.M. Palet).

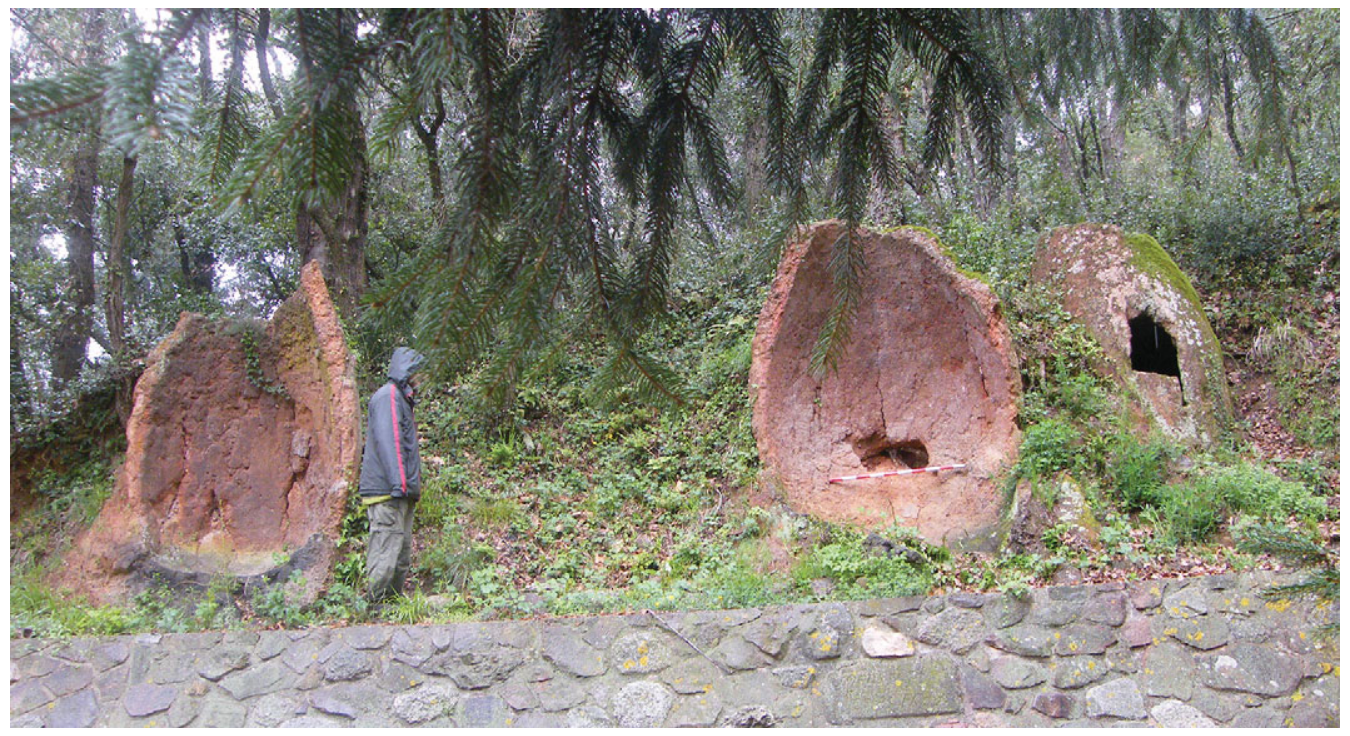

Figure 5. Medieval pitch kilns in Montseny Massif (c) H.A. Orengo).

are correlated to the accumulation rate of pine pollen (Figure 6), a distinct relationship becomes evident between pitch production and the decrease of pine pollen. M157 (the only kiln for which both initial and final dates have been obtained) was in use during a period of slightly over 200 years. The latest use of kilns M219 and M052 were dated to $147 \pm 77 \mathrm{cal}$ AD (Poz-32019) and 155 $176 \mathrm{cal} \mathrm{AD} \mathrm{(Poz-13626)} \mathrm{respectively.} \mathrm{Assuming} \mathrm{for} \mathrm{these} \mathrm{kilns}$ a similar span of activity to that documented for M157, then the activity of M219 would have started around $50 \mathrm{BC}$, when the pine pollen accumulation rate starts descending. At the end of their use, a pronounced increase in the pine accumulation rate is observed, whose (C) Antiquity Publications Ltd. 
Hector A. Orengo et al.

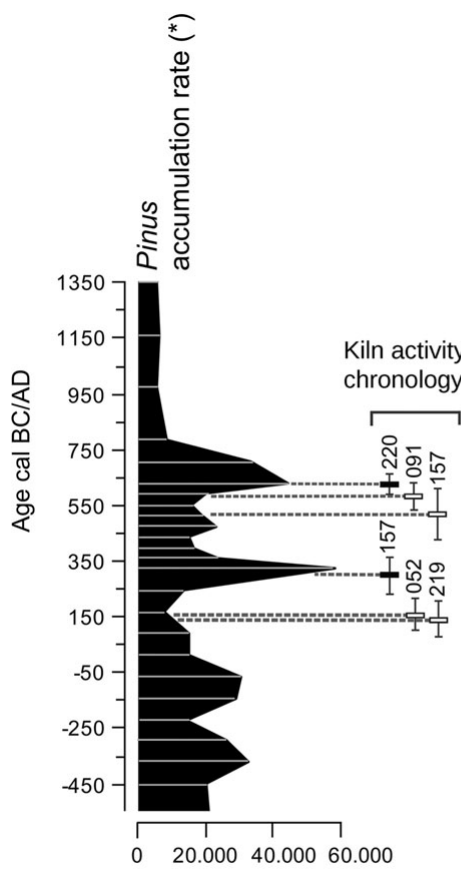

$\left({ }^{*}\right)$ Accumulation rates are expressed as grains/spores.cm ${ }^{2} \mathrm{yr}$
Percentage values

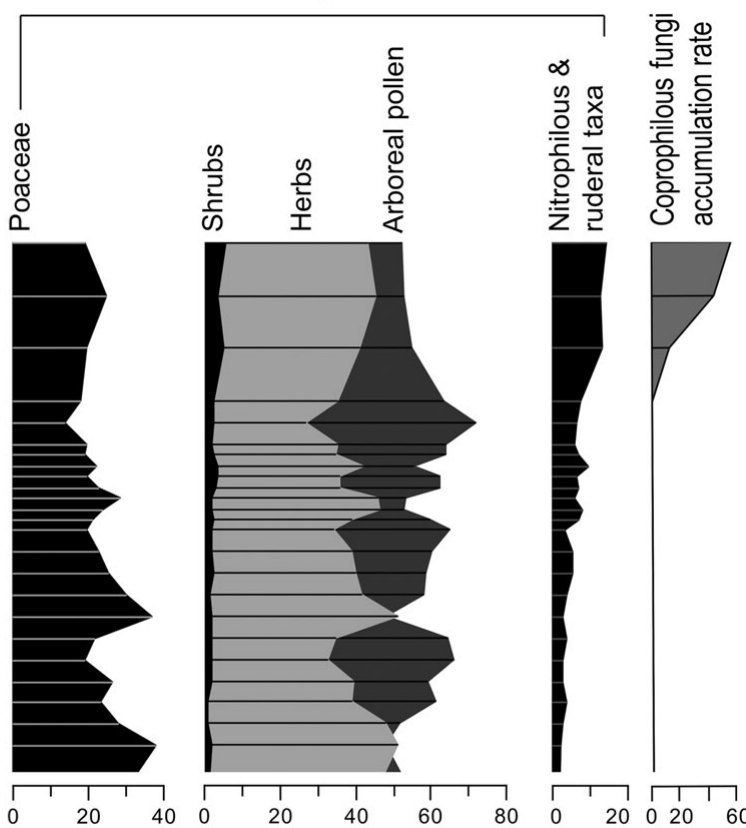

Start date I End date I

Figure 6. Comparison of RDO palaeoenvironmental data with the start and end date of the kilns (C) Ana Ejarque, modified by H.A. Orengo).

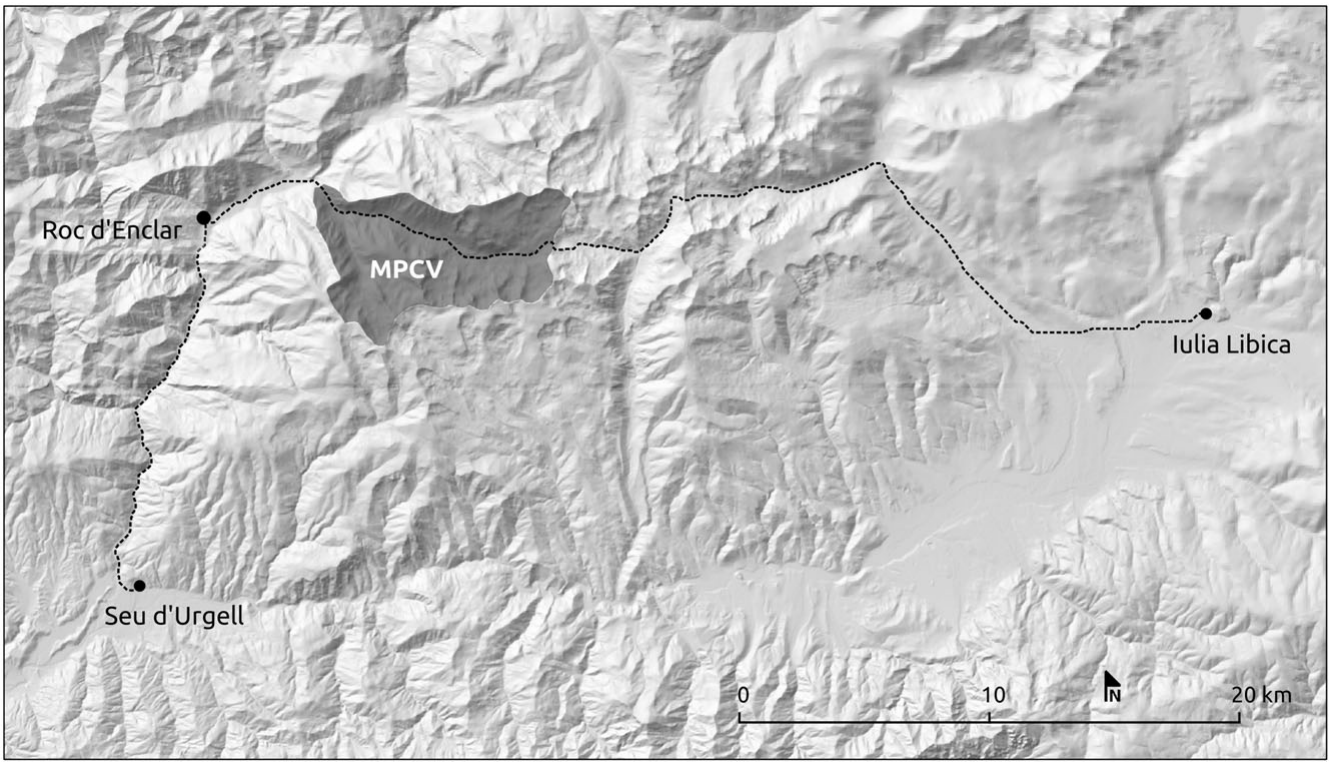

Figure 7. MPCV and the sites and routes mentioned in the text (C) H.A. Orengo).

(C) Antiquity Publications Ltd. 


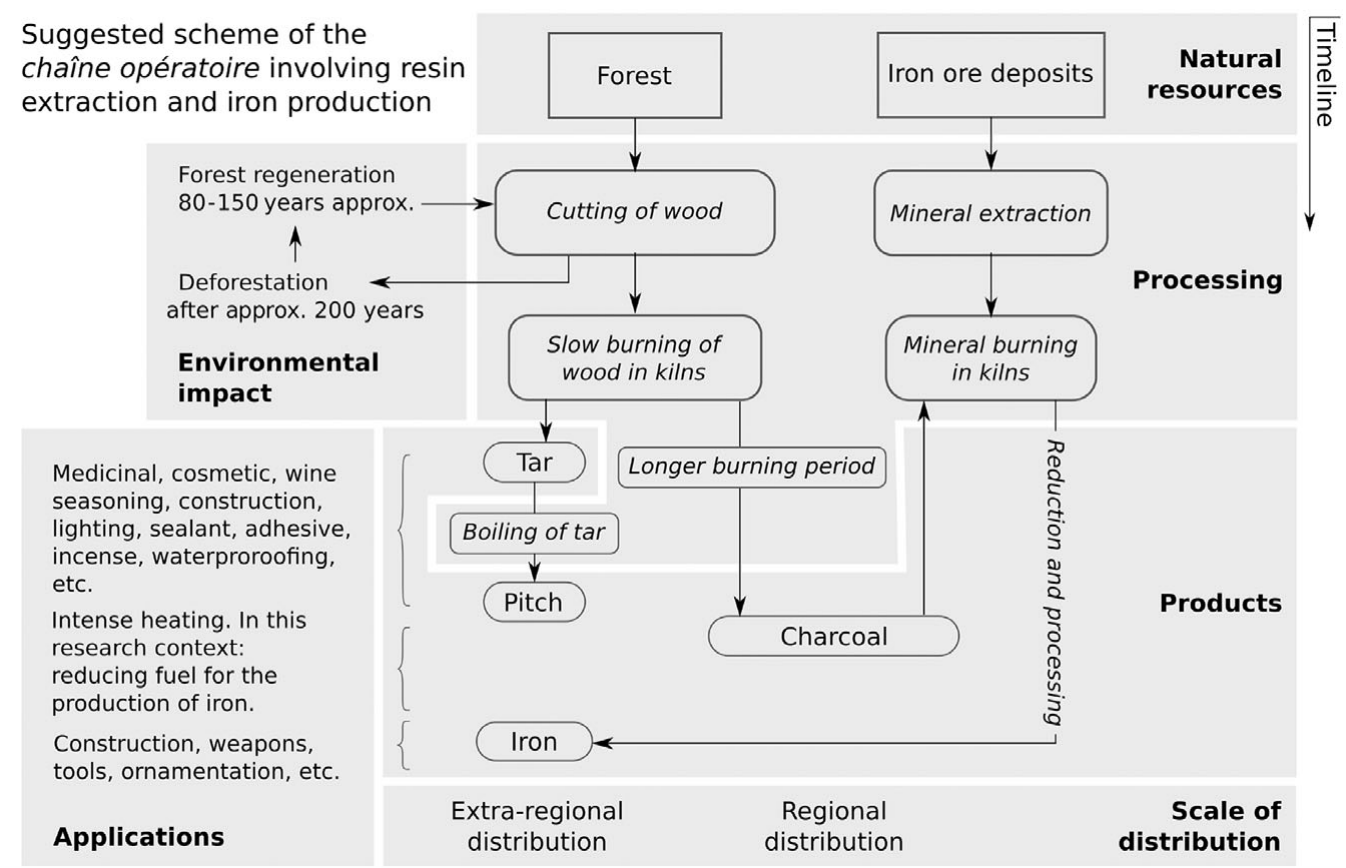

Figure 8. Suggested scheme of the chaîne opératoire involving resin extraction and iron production in the study area (c) H.A. Orengo).

peak coincides with the start of activities of kiln M157 in 312 \pm 77 cal AD (Poz-22563) and, probably, M091, for which a similar period of activity is assumed. It is at exactly this point that pollen accumulation rates appear to drastically decrease. The end of kiln M0157 in 537士100 cal AD (Poz-28428) and M091 in 592 51 cal AD (Poz-32024) marks the increase of pollen accumulation rates, which again reverted with the start of the activity of kiln M220 in 616 42 cal AD (Poz-32020). The maintenance of low pine accumulation rates from $\mathrm{AD} 750$ onwards seems to be related to the maintenance of local open grasslands for pasture, as attested by the increase of dung-related fungal spores and of nitrophilous and ruderal taxa (Figure 6), rather than the continuity of resin extraction in the area (Ejarque 2009).

This correlation of kilns with pollen dates demonstrates the existence of three different pitch production episodes. In each episode, at least two resin kilns were active at the same time. One of these structures could take several days to distil one wood load and had to be continuously under supervision to avoid intensive burning. The working of several kilns at the same time would allow continuous production; the recovery of charcoal and pitch from a recently extinguished kiln and the preparation of the next wood load could be done while other kilns were burning. Such a large-scale and continuous pitch exploitation system did not impact negatively the local pine forest regeneration, as suggested by the regular pine forest recovery recorded at the RDO pollen sequence. This indicates that, at least for this area, there was sustainable exploitation of highland forests in antiquity.

(C) Antiquity Publications Ltd. 


\section{The supply system}

Given that the pitch kilns located in the Pyrenees, Massif Central, Oberbronn and Sweden (described above) differ in their typology, it could be claimed that they represent local variations linked to different cultural traditions. The typological diversity in pitch-extraction practices in these areas - which during the Roman period were occupied by different cultural groups-plus the use of traditional Celtic V-shaped ceramic containers in the case of the Massif Central industries, strongly suggest the existence of pre-Roman local pitch production traditions. Sweden never belonged to the Roman Empire and therefore the specificity of its production method may also be the product of local traditions, varying little until the modern period (Hjulström et al. 2006).

Although there are differences between the Massif Central pitch industry and that attested at the MPCV, both seem to represent large-scale production. They are located in mountain areas where forest resources played an important role in the local economy. In both the Pyrenees and the Massif Central (Trintignac 2003: 242), the industries seem to be seasonal, since their sites are covered in snow from October to April, and are only accessible after the snow melts. Both involve long-term intensive exploitations with periodic breaks for forest regeneration, driven by the exhaustion of forest resources.

Pliny specifies that in Europe pitch is extracted by the action of fire from the Pinus mugo (Nat. Hist. 16.21; Bostock \& Riley 1855). Pinus mugo ssp. uncinata has a high resin content, but is very restricted in its spatial distribution, occupying an altitudinal belt between 1600 and 2400m asl (López 2007: 197-98). In fact, Pliny reproduces the opinion that "in mountainous localities this liquid is produced in the greatest abundance" (Nat. Hist. 16.23; Bostock \& Riley 1855), something also reflected in other classical works such as Strabo's Geography (4.6.9; Hamilton \& Falconer 1903) and Dionysius of Halicarnassus' Roman Antiquities (20.15; Cary 1950). Both archaeological and written sources thus agree in characterising pitch production as typical of mountain areas, where resin-rich mountain pine can be exploited.

This type of mountain intensive forest exploitation can only be economically feasible in market-oriented economies with a well-developed distribution network. In fact, the cost of concentrating the production in mountain areas (relatively far from the main distribution markets) could be compensated for by higher production that could be practised only in areas covered with high-resin-content trees. It seems, therefore, no coincidence that all the resin kilns found in the MPCV were aligned to the main route joining Roc d'Enclar, the central settlement in Andorra during this period, with the Roman city of Iulia Libica (Figure 7), $30 \mathrm{~km}$ to the east (Orengo 2010: 289-90), which acted as the political, administrative and economic centre of the region.

The Pyrenean kilns' specific typology also suggests intensive use. They are sturdy and well built structures, intended to last for long periods of time, while their diameter suggests they could admit a fairly high quantity of wood. Also, archaeological evidence suggests several of them were in use at the same time. Palaeoecological data confirm that their landscape impact was considerable, since they were able to deforest the immediate area in periods of around 200 years. Thus, they could have been used continuously and there would be no need to replace them with new ones for every episode of pitch production. 
In the case of Pyrenean and Gallic pitch production sites, the integration of these regional industries in the Roman Empire meant access to an international, unified market with a relatively secure and wide trade network. This Roman 'globalised' economy would allow traditional industries and activities to become specialised and intensive according to market demands. Unsurprisingly, therefore, mountain areas with specific natural resources, such as extensive high-quality grasslands, resin-rich pine forests or ore, developed an intensive specialised industry focused on long-distance trade.

\section{Pitch and iron: an integrated economy}

In the MPCV kilns, charcoal was a useful by-product of pitch production, and could also have been commercialised in large quantities. The fact that no charcoal accumulations have been located in the kilns' surroundings indicates that this was probably transported elsewhere. Charcoal had multiple applications. Of particular relevance in the case of Andorra is its use as fuel in iron reduction activities during the medieval and modern periods, during exploitation of the significant ore deposits in the area. Iron production from the fifth-eighth centuries AD was documented at the site of Roc d'Enclar (Rovira \& Solans 1997), 12km west of the main concentration of resin kilns (Figure 7). Many other iron exploitation and treatment activities were also documented in neighbouring sites, such as Goleró $(2020 \mathrm{~m}$ asl), $20 \mathrm{~km}$ south of the MPCV, where three iron kilns were found, dating from the firstthird centuries AD (Palet et al. 2011). This iron production activity would have required huge quantities of charcoal. In Vallferrera, $25 \mathrm{~km}$ west of the MPCV, where Roman iron exploitation activities were very intensive, it was possible to relate iron slag and charcoal kilns as part of a single productive process (Pèlachs et al. 2009).

Both written documentation and archaeological evidence concur that pitch and iron production in the eastern Pyrenees during the Roman period were related and could have been part of an integrated economic system of organised and intensive exploitation, where charcoal-pitch production's by-product-would be employed in the extraction of iron (Figure 8). This would also explain the existence of an historical tithe on both pitch and iron in Andorra from, at latest, the ninth century: these were possibly the only products in Andorra that had an organised exploitation and an extra-local distribution (Orengo 2010: 272-73). Perhaps this link between pitch and iron production-non-existent in the case of the Massif Central industries, where the production method would not include the manufacture of charcoal-would also explain the persistence of pitch production activities in the MPCV until the seventh century AD, long after the Roman trade networks would have fallen into disuse.

\section{Conclusions}

This paper presents the first comprehensive account of pitch production during the Roman period. The combination of closely related archaeological and fine resolution palaeoenvironmental data has allowed the modelling of the output of both pitch and charcoal. The intensity of Roman forest exploitation in the MPCV illustrates the diversification and specialisation of the Roman economy, which, with the maintenance

(C) Antiquity Publications Ltd. 
of commercial networks and distribution markets, not only allowed but encouraged local traditional activities to become participants in resource distribution.

This study further illustrates how mountain landscapes, traditionally regarded as marginal and oriented economically to livestock grazing, encompass rather diverse and complementary economic activities, including forest exploitation (for resin, charcoal and wood) and ore extraction and treatment. These activities were complementary and sustainable in nature. As the Pyrenean data suggest, a balance between intensive exploitation and the regeneration of resources was sustained for at least five centuries until the onset of early medieval intensive pastoral practices. These activities were, at least during the Roman period, integrated into supra-regional economic networks to which they contributed highly necessary and specialised products.

\section{Acknowledgements}

The Madriu-Perafita-Claror Valley (MPCV) Project was an international multidisciplinary project led by the Landscape Archaeology Research Group (GIAP) of the Catalan Institute of Classical Archaeology, and the Seminar of Prehistoric Study and Research (SERP) of the University of Barcelona, aiming to investigate humanenvironment interactions in high mountain areas. The project was funded by the Andorran Government (Area de Recerca Històrica), and the AGAUR from the Catalan Autonomous Government (EXCAVA program) and by the Catalan Institute of Classical Archaeology (ICAC). Hector Orengo received a BE grant from the AGAUR to conduct documentary research in the National Historic Archive of Andorra. The authors would also like to thank Prof. M. Carver for his excellent editing input and two anonymous reviewers for their useful comments. Arnau Garcia (ICAC) and Itxaso Euba (ICAC) generously provided ideas and material relevant to this research.

\section{References}

ABRAHAM, H. 1920. Asphalts and allied substances: their occurrence, modes of production, uses in the arts and methods of testing. New York: D. Van Nostrand.

Albenque, A. 1947. Inventaire de l'archéologie gallo-romaine du département de l'Aveyron. Rodez: P. Carrère.

ANDRÉ, J. 1964. La résine et la poix dans l'antiquité: technique et terminologie. L'Antiquité classique 33: 86-97.

BALSAN, L. 1951. L'industrie de la résine dans les Causses et son extension dans l'Empire romain. Gallia 9: 53-55.

BEgLINGER, E. 1958. Distillation of resinous wood (Report 496 [revised]). Madison (WI): Forest Products Laboratory, United States Department of Agriculture, Forest Service.

Bostock, J. \& H.T. RiLey. 1855. The Natural History of Pliny. London: Henry G. Bohn.

CARY, E. 1950. The Roman Antiquities of Dionysius of Halicarnassus (Loeb Classical Library). Cambridge (MA): Harvard University Press.
Connan, J., B. Maurin, L. Long \& H. Sebire. 2002. Identification of pitch and conifer resin in archaeological samples from the Sanguinet lake (Landes, France): export of pitch on the Atlantic Ocean during the Gallo-Roman period. Revue d'Archéométrie 26: 177-96.

EJARQUE, A. 2009. Génesis y configuración microregional de un paisaje cultural pirenaico de alta montaña durante el Holoceno: estudio polínico y de otros indicadores paleoambientales en el valle de Madriu-Perafita-Claror (Andorra). Unpublished PhD dissertation, Universitat Rovira i Virgili.

Ejarque, A., Y. Miras, S. Riera, J.M. Palet \& H.A. ORENGO. 2010. Testing microregional variability in the Holocene shaping of high mountain cultural landscapes: a palaeoenvironmental case-study in the eastern Pyrenees. Journal of Archaeological Science 37: 1468-79.

EUBA, I. 2009a. Informe antracológico de la ES 157, horno de resina (s. IV d. C.) del yacimiento de Orris de Setut III (Valle del Madriu, Andorra). Report prepared for the Catalan Institute of Classical Archaeology, Tarragona. 
- 2009b. Explotación de los recursos forestales desde el Neolítico hasta la época moderna en los valles de la Vansa-sierra del Cadi (Alt Urgell) y en el valle del Madriu (Andorra) (Serie Documenta 9). Tarragona: Institut Català d'Arqueologia Clàssica.

Hamilton, H.C. \& W. Falconer. 1903. The Geography of Strabo (Bohn's Classical Library). London: George Bell \& Sons.

Hjulström, B., S. IsaKsson \& A. Hennius. 2006. Organic geochemical evidence for pine tar production in Middle Eastern Sweden during the Roman Iron Age. Journal of Archaeological Science 33: 283-94.

HORT, A. 1916. Theophrastus' Enquiry into Plants and minor works On Odours and Weather Signs (Loeb Classical Library). London: William Heinemann.

JONCHERAY, J.-P. 1977. Mediterranean hull types compared: 2. Wreck F from Cape Dramont (Var), France. International Journal of Nautical Archaeology 6: 3-7.

LOIR, E. 1940. L'industrie de la résine dans les Causses à l'époque Gallo-romaine. Nancy: Bailly et Wettstein.

LÓPEZ, G. 2007. Guía de los árboles y arbustos de la Península Ibérica y Baleares. Madrid: Mundi-Prensa.

Miras, Y., A. Ejarque, S. Riera, J.M. Palet, H.A. Orengo \& I. EubA. 2007. Dynamique holocène de la végétation et occupation des Pyrénées andorranes depuis le Néolithique ancien, d'après l'analyse pollinique de la tourbière de Bosc dels Estanyons (2180m, Vall del Madrid, Andorra). Comptes Rendus Palevol 6: 291-300.

Orengo, H.A. 2010. Arqueología de un paisaje cultural pirenaico de alta montaña. Dinámicas de ocupación del valle del Madriu-Perafita-Claror (Andorra). Unpublished PhD dissertation, Universitat Rovira i Virgili.

Palet, J.M., H.A. Orengo, A. Ejarque, I. Euba, Y. Miras \& S. RiEra. 2011. Formas del paisaje de montaña y ocupación del territorio en los Pirineos orientales en época romana: estudios pluridisciplinares en el valle del Madriu-PerafitaClaror (Andorra) y en la Sierra del Cadí (Cataluña). Bollettino di Archeologia on line 1: 67-79.
PARKER, A.J. 1992. Ancient shipwrecks of the Mediterranean and the Roman provinces (British Archaeological Reports international series 580). Oxford: Archaeopress.

Pèlachs, A., J. Nadal, J.M. Soriano, D. Molina \& R. Cunill. 2009. Changes in Pyrenean woodlands as a result of the intensity of human exploitation: 2000 years of metallurgy in Vallferrera, northeast Iberian Peninsula. Vegetation History and Archaeobotany 18: 403-16.

Reimer, P.J., M.G.L. Baillie, E. Bard, A. Bayliss, J.W. Beck, P.G. Blackwell, C. Bronk Ramsey, C.E. BuCK, G.S. Burr, R.L. EdWARdS, M. Friedrich, P.M. Grootes, T.P. Guilderson, I. Hajdas, T.J. Heaton, A.G. Hogg, K.A. Hughen, K.F. Kaiser, B. Kromer, F.G. McCormac, S.W. Manning, R.W. Reimer, D.A. Richards, J.R. SOUTHON, S. Talamo, C.S.M. Turney, J. Van der Plicht \& C.E. WeYhenMeYer. 2009. IntCal09 and Marine09 radiocarbon age calibration curves, 0-50,000 years cal BP. Radiocarbon 51: 1111-50.

RENAUD, J. 1963. Les résiniers gallo-romains du Haut-Forez. Bulletins des Groupes de Recherche Archéologique du Département de la Loire 2: 58-61.

Rovira, M.C. \& J. SOLANS. 1997. Les activitats metallúrgiques, in X. Llovera i Massana (ed.) Roc d'Enclar. Transformacions d'un espai dominant, segles $I V-X I X$ (Monografies del Patrimoni Cultural d'Andorra 4): 351-65. Andorra la Vella: Govern d'Andorra.

Rule, M. \& J. Monaghan. 1993. A Gallo-Roman trading vessel from Guernsey (Guernsey Museum Monographs 5). Guernsey: Guernsey Museums and Galleries.

Soutou, A. 1959. L'Atelier de résiniers Gallo-Romain de Puech-Margue (Commune de la Cresse, Aveyron). Pallas 8: 85-90.

TrintignAC, A. 2003. La production de poix dans la cité des Gabales (Lozère) à l'époque gallo-romaine. Revue Archéologique de Picardie 1/2: 239-48.

Ulrich, H. 1939. Un four à poix (?) de l'époque gallo-romaine près d'Oberbronn. Cahiers d'archéologie et d'histoire d'Alsace 8: 51-56.

VIRÉ, A. 1943. La résine des Causses à l'époque gallo-romaine, tombeau, habitation et four gallo-romains à Montpellier le vieux. Revue des Etudes Anciennes 45: 241-52.

Received: 6 June 2012; Accepted: 21 August 2012; Revised: 17 September 2012

(C) Antiquity Publications Ltd. 